\title{
ASSESSMENT OF CHEMICAL COMPOSTION AND PHYSICAL PROPERTIES OF GLUTEN- FREE COMPOSITE FLOUR AND QUALITY ATTRIBUTES OF PAN BREAD
}

(Received: 29.8.2017)

\author{
By \\ E. A. A. Abd Rabou \\ Home Economics Department, Faculty of Specific Education, Aswan Univresity, Egypt.
}

\begin{abstract}
Gluten-free composite flour was prepared by substituting rice flour by chickpea or white corn at different levels. The chemical composition and physical properties were studied. Furthermore, the effect of different levels of water on pan bread quality were studied. The results showed that increasing the replacement levels of rice flour with chickpea or white corn, increased protein, fat and ash. Moreover, water or oil absorption capacity of both composite flours increased. Bulk density of rice-chickpea increased, but decreased in rice-white corn composite flour. In addition, the initial gelatination temperature of rice-chickpea composite flour increased, but decreased with rice-white corn. Moreover, the gelatinization temperature and maximum gelatinization of both types of composite flour decreased. Also, increasing levels of the used water lead to decreasing the baking loss of pan bread containing $20 \%$ chickpea and that contained $67 \%$ white corn and specific volume of pan bread containing $20 \%$ chickpea flour also gradually decreased, but increased in pan bread containing 67\% corn. Regarding sensory properties, it improved in both types of pan bread, specially taste and odor. Generally, both chickpea and white corn replacing rice flour can improve the nutrition value and physical properties of composite flour. Also, increasing the water levels can improve the physical properties and some sensory properties of pan bread.
\end{abstract}

Key words: Composite flour, chickpea, rice, white corn, pan bread.

\section{INTRODUCTION}

Demanding Gluten-free products increased due to the growing number of people who suffer celiac disease, and thereby need gluten-free diet (Padalino et al., 2016). So, all the products prepared from wheat, rye, barley, and oat must be replaced by corn, rice, millet equivalents and various types of starch (corn, rice and potato) or appropriate mixtures (Lazaridou et al., 2007 and Hegazy et al., 2009). The use of composite flour for bread making is gradually gaining prominence worldwide due to some economic and nutritional reasons (Yaseen et al., 2010 and Roshid et al., 2016). Composite flour can be defined as a mixture of several flours, starches and other ingredients obtained from roots, tubers, cereals and legumes with or without the addition of wheat flour in bakery and pastry products (Shittu et al., 2007 and De la Hera et al., 2013).

Rice flour is one of the most suitable flours for baking gluten-free products due to its hypoallergenic properties, soft taste, white color, low sodium content, easily digestible carbohydrates and mild flavor and pale appearance
(Lopez et al., 2004, and Mirzaei and Movahed, 2013). Legumes with high protein content are widely used as composite flour in the production of bakery products (Mishra and Chandra, 2012). So, chickpea should be used as an ingredient in the bakery industry such as functional and healthy food formulations as biscuits, snack foods, bread, breakfast food, and cakes (Youssef, 2015). Also, maize (corn) flour could be utilized as an ingredient for the production of gluten-free bread; it is suitable for class consumption, together with rice. However, its use in such formulations is usually limited, probably due to the distinctive flavor and intense yellow color (Schober et al., 2010 and De la Hera et al., 2013).

Bread is considered an important food product in most regions of the world. Therefore, it should contain required nutritional value and curative properties (Mirzaei and Movahed, 2013 and Mollakhalili Meybodi et al., 2015). Hydrocolloids (such as xanthan gum, guar gum and pectin) are added to naturally gluten-free flour to minmic the viscoelastic properties of gluten and to improve sensory properties, structure, and shelf-life of these 
products (Moore et al., 2004; Lazaridou et al., 2007). For obtaining high-volume and soft crumb texture bread, different non gluten proteins as soybean, pea, egg, and dairy proteins have been included in gluten-free formulations to provide structure and gas-retaining properties of the dough and to improve simultaneously the nutritional quality structure, mouth feel, acceptability and shelf life (Korus et al., 2006 and Mariotti et al., 2009).

Gluten-free bread dough is a more fluid system similar to that of cake batter due to the lack of a gluten matrix (Gallagher et al., 2004; Moore et al., 2004 and Torbica et al., 2010). The batter becomes meringue-like in fermentation. Thus, the walls of the bubbles in the rising batter should be more fragile than those in wheat dough. It has been reported that a mixture of cereal flour improves the quality of gluten-free bread (Sciarini et al., 2010). So the quantity of added water is considered very important for the distribution of the dough materials, their hydration prepared by replacing rice flour by white corn at the ratios of $17,33,50$, and $67 \%$. Afterwards, studying the effect of five levels of water, i.e., 70, $80,90,100$ and $110 \%$, based on flour mass, on quality attributes such as physical and sensory properties of two types of composite flour where the first one contained $20 \%$ chickpea flour, and the second contained $67 \%$ white corn flour.

\section{MATERIALS AND METHODS 2.1. MATERIALS}

Peeled roasted chickpea, rice flour, white corn flour, salt, full fat milk powder, dry yeast powder, sugar, Arabic gum, egg, and oil were obtained from the local markets of Aswan city, Egypt.

\subsection{METHODS}

\subsubsection{Preparation of composite flour}

Peeled roasted chickpea was milled by house mincer. And rice-chickpea or rice-white corn composite flour was prepared by replacing rice flour by chickpea or white corn flour according to the formula shown in Table (1).

Table (1): Formula of composite flour.

\begin{tabular}{|c|c|c|c|c|c|c|c|c|}
\hline \multirow[b]{2}{*}{ Constituents } & \multicolumn{4}{|c|}{ Rice- chickpea composite flour } & \multicolumn{4}{|c|}{ Rice -white corn composite flour } \\
\hline & $\begin{array}{c}5 \% \\
\text { CHF }\end{array}$ & $\begin{array}{l}10 \% \\
\text { CHF }\end{array}$ & $\begin{array}{l}15 \% \\
\text { CH F }\end{array}$ & $\begin{array}{l}20 \% \\
\text { CHF }\end{array}$ & $\begin{array}{l}17 \% \\
\text { WCF }\end{array}$ & $\begin{array}{l}\text { 33\% } \\
\text { WCF }\end{array}$ & $\begin{array}{l}\mathbf{5 0 \%} \\
\text { WCF }\end{array}$ & $\begin{array}{l}67 \% \\
\text { WCF }\end{array}$ \\
\hline Rice flour & 95 & 90 & 85 & 80 & 83 & 67 & 50 & 33 \\
\hline White corn flour & - & - & - & - & 17 & 33 & 50 & 67 \\
\hline Chickpea flour & 5 & 10 & 15 & 20 & -- & -- & -- & -- \\
\hline
\end{tabular}

CHF: Chickpea flour. WCF: white corn flour.

and the gluten protein network development (Ahmed, 2013).

For these reasons, the present investigation was conducted to study the quality attributes of two composite flours. The first one was prepared by replacing rice flour by chickpea flour at the ratios of 5, 10, 15 and $20 \%$ and the second one was

\subsubsection{Preparation of pan bread from rice- chickpea and rice-white corn blends}

Pan bread ingredients were prepared according to the formula shown in Table (2). Sugar and yeast powder were dissolved in 50-60 ml of warm water $\left(35^{\circ} \mathrm{C}\right)$, then mixed together and spent about 5 minutes to activate the yeast. All dry and wet

Table (2): Formula of pan bread.

\begin{tabular}{|c|c|c|c|c|c|c|c|c|c|c|}
\hline \multirow[b]{2}{*}{$\frac{\text { Ingredient }(\mathrm{g})}{\text { Products }}$} & \multicolumn{5}{|c|}{ Rice pan bread with $20 \%$ chickpea flour } & \multicolumn{5}{|c|}{ Rice pan bread with $67 \%$ corn flour } \\
\hline & $\begin{array}{c}70 \% \\
\text { water }\end{array}$ & $\begin{array}{c}80 \% \\
\text { water }\end{array}$ & $\begin{array}{c}90 \% \\
\text { water }\end{array}$ & $\begin{array}{l}100 \% \\
\text { water }\end{array}$ & $\begin{array}{l}110 \% \\
\text { water }\end{array}$ & $\begin{array}{l}70 \% \\
\text { water }\end{array}$ & $\begin{array}{c}\mathbf{8 0 \%} \\
\text { water }\end{array}$ & $\begin{array}{l}90 \% \\
\text { water }\end{array}$ & $\begin{array}{l}100 \% \\
\text { water }\end{array}$ & $\begin{array}{l}110 \% \\
\text { water }\end{array}$ \\
\hline 80\% RF- $20 \%$ CHF & 250 & 250 & 250 & 250 & 250 & - & - & - & - & - \\
\hline $33 \%$ RF -67\% WCF & - & - & - & - & - & 250 & 250 & 250 & 250 & 250 \\
\hline Sugar & 7 & 7 & 7 & 7 & 7 & 7 & 7 & 7 & 7 & 7 \\
\hline Full fat milk powder & 20 & 20 & 20 & 20 & 20 & 20 & 20 & 20 & 20 & 20 \\
\hline Oil & 30 & 30 & 30 & 30 & 30 & 30 & 30 & 30 & 30 & 30 \\
\hline Hen egg (whole, fresh) & 50 & 50 & 50 & 50 & 50 & 50 & 50 & 50 & 50 & 50 \\
\hline Salt & 2 & 2 & 2 & 2 & 2 & 2 & 2 & 2 & 2 & 2 \\
\hline Yeast powder & 5 & 5 & 5 & 5 & 5 & 5 & 5 & 5 & 5 & 5 \\
\hline Arabic gum & 3 & 3 & 3 & 3 & 3 & 3 & 3 & 3 & 3 & 3 \\
\hline Water & 175 & 200 & 225 & 250 & 275 & 175 & 200 & 225 & 250 & 275 \\
\hline Water as mass flour \% & 70 & 80 & 90 & 100 & 110 & 70 & 80 & 90 & 100 & 110 \\
\hline
\end{tabular}

CHF: Chickpea flour. RF: Rice flour . WCF: white corn flour. 
ingredients were mixed with active yeast for 5 minutes at $35^{\circ} \mathrm{C}$. The batter was put in a metal pan, covered with wet cloth and left in a warm place at $35^{\circ} \mathrm{C}$ to ferment for 40 minutes and baking in a hot oven at $180^{\circ} \mathrm{C}$ for $30-40$ minutes. Finally, all pan bread samples were cooled at room temperature $\left(30^{\circ} \mathrm{C}\right)$ and packed in low-density polyethylene bags for further analysis.

\subsubsection{Chemical analysis}

Moisture, protein, ash and fat of flour and its blends were determined according to the methods described by A.O.A.C. (2005). Total carbohydrates were calculated by difference as following:

Carbohydrates $\%=100$ - (moisture $\%+$ protein $\%$ + fat $\%+$ ash \%).

\subsubsection{Physical properties of flour and its blends}

\subsubsection{Bulk and packed density determination}

The bulk density and packed density of rice, white corn, chickpea flour and its blends were determined as the methods described by Mpotokwane et al., (2008). The sample (50 g) was put into a $100 \mathrm{ml}$ graduated cylinder and tapped 20-30 times. The bulk density was calculated after tapping as weight per unit volume of the sample. Also, packed density was calculated after the pressed sample by the rubber piston (a rubber rod with a rubber plug) as weight per unit volume of the sample.

\subsubsection{Water absorption and oil absorption capacity}

Water and oil absorption capacity of rice, white corn, chickpea flour and its blends were determined according to methods described by Oyeyinka et al., (2013).

\subsubsection{Amylograph characteristics}

Amylograph characteristics as initial gelatinization temperature (IGT) the gelatinization temperature (GT), and maximum gelatinization (Max G) of rice, white corn flours, and it blends were determined according to A.A.C.C., (2000) by using Amylograph-E (Brabender Gmb H\&Co. KG, Duisburg, Germany) at rheological Lab, Department of Bread And Dough, Egyptian Baking Technology Center, Elharm, Giza, Egypt.

\subsubsection{Physical properties of pan bread}

Weight $(\mathrm{g})$ and volume $\left(\mathrm{cm}^{3}\right)$ of the resulted loaves of pan bread samples were measured by the scale and replaced displacement method according to A.A.C.C., (2000). Specific volume $\left(\mathrm{cm}^{3} / \mathrm{g}\right)$ was calculated by dividing loaf volume by its weight.

\subsubsection{Sensory properties of pan bread}

All pan bread samples were evaluated for crust color, crumb color, texture, cell distribution, taste, odor and general appearance according to method of Gujral and Rosell (2004).

\subsubsection{Statistical analysis}

All data were analyzed using the software, statistical package for social science (SPSS) version 17.00 SPSS Inc., Chicago, IL, USA at the 0.05 level. The results were expressed as means \pm standard deviation (SD). Data were analyzed by using one-way analysis of variance (ANOVA) for continuous variables. according to SPSS, (2008). P values <0.05 were considered to be statistically significant.

\section{RESULTS AND DISCUSSION \\ 3.1. Chemical composition of rice, chickpea, white corn flours and its blends}

The results presented in Table (3) showed the chemical composition of rice, chickpea, white corn flours and its blends. The results showed that chickpea had the highest contents of protein, fat and ash followed by white corn then rice flour respectively. So, as increasing the levels of replacing rice flour by chickpea or white corn flour, protein, fat, and ash contents were gradually increased, but moisture and carbohydrates were decreased. The results of chemical composition of rice and white corn flour confirmed those of Wani and Kumar (2015).

Besides, the chemical composition of white corn flour was in agreement with that of Hussein et al. (2013) and Begum et al. (2013). The results of chemical composition of chickpea flour were in agreement with those of Wani and Kumar (2014) and Man et al. (2015).

All the results of the effect of adding chickpea flour to rice flour are in ageenent with those of Alajaji and El-Adawy (2006), Izembaeva et al., (2013) and Man et al. (2015). They reported that a legume, in general, especially chickpea flour is a good source of proteins, carbohydrates, several water soluble vitamins, and minerals. Legumes, in general, make a major contribution to human nutrition. It could be an ideal ingredient for improving the nutritional value of bread and bakery products.

\subsection{Physical properties of rice, chickpea, white corn flours and its blends}

The results presented in Table (4) showed the physical properties of rice, chickpea, white corn flours and its blends. These results indicated that bulk density values of rice-chickpea blends were gradually increased, but it were slightly decreased in rice -white corn flour blends as replacing levels were increased.

These results might be due to higher bulk density of chickpea flour compared to rice flour and white corn flours compared to rice flour, but it 
Table (3): Chemical composition of rice, chickpea, white corn flours and its blends (on dry weight).

\begin{tabular}{|c|c|c|c|c|c|c|}
\hline Constituents & $\begin{array}{c}\text { Moisture } \\
(\%)\end{array}$ & $\begin{array}{c}\text { Dry matter } \\
(\%)\end{array}$ & $\begin{array}{c}\text { Protein } \\
(\%)\end{array}$ & $\begin{array}{l}\text { Fat } \\
(\%)\end{array}$ & $\begin{array}{l}\text { Ash } \\
(\%)\end{array}$ & $\begin{array}{c}\text { Carbohydrate } \\
(\%)\end{array}$ \\
\hline Rice flour & $8.59 \pm 0.04 \mathrm{~b}$ & $91.41 \pm 0.04 \mathrm{~b}$ & $6.21 \pm 0.03 \mathrm{c}$ & $1.22 \pm 0.02 \mathrm{c}$ & $0.33 \pm 0.01 \mathrm{c}$ & $92.24 \pm 0.06 \mathrm{a}$ \\
\hline White corn flour & $10.95 \pm 0.07 \mathrm{a}$ & $89.05 \pm 0.07 \mathrm{c}$ & $11.04 \pm 0.05 \mathrm{~b}$ & $3.22 \pm 0.02 \mathrm{~b}$ & $1.89 \pm 0.08 \mathrm{~b}$ & $83.85 \pm 0.09 \mathrm{~b}$ \\
\hline Chickpea flour & $7.58 \pm 0.06 \mathrm{c}$ & $92.42 \pm 0.06 \mathrm{a}$ & $24.56 \pm 0.02 \mathrm{a}$ & $7.52 \pm 0.03 \mathrm{a}$ & $3.74 \pm 0.06 \mathrm{a}$ & $64.18 \pm 0.03 \mathrm{c}$ \\
\hline $\mathbf{P}<$ & 粎**; & ****** & 栦** & ****** & ****** & ******* \\
\hline \multicolumn{7}{|c|}{ Rice-chickpea composite flour } \\
\hline $5 \%$ chickpea flour & $8.54 \pm 0.02 \mathrm{a}$ & $91.46 \pm 0.02 \mathrm{c}$ & $7.13 \pm 0.04 \mathrm{~d}$ & $1.54 \pm 0.03 \mathrm{~d}$ & $0.50 \pm 0.02 \mathrm{~d}$ & $90.83 \pm 0.06 a$ \\
\hline $10 \%$ chickpea flour & $8.49 \pm 0.04 \mathrm{ba}$ & $91.51 \pm 0.04 \mathrm{~b}$ & $8.05 \pm 0.07 \mathrm{c}$ & $1.85 \pm 0.03 \mathrm{c}$ & $0.67 \pm 0.05 \mathrm{c}$ & $89.43 \pm 0.10 \mathrm{~b}$ \\
\hline $15 \%$ chickpea flour & $8.44 \pm 0.05 \mathrm{~b}$ & $91.56 \pm 0.05 \mathrm{ba}$ & $8.96 \pm 0.04 \mathrm{~b}$ & $2.17 \pm 0.02 \mathrm{~b}$ & $0.84 \pm 0.02 b$ & $88.03 \pm 0.08 \mathrm{c}$ \\
\hline $20 \%$ chickpea flour & $8.39 \pm 0.03 c$ & $91.61 \pm 0.03 \mathrm{a}$ & $9.88 \pm 0.02 \mathrm{a}$ & $2.48 \pm 0.03 \mathrm{a}$ & $1.01 \pm 0.03 \mathrm{a}$ & $86.63 \pm 0.02 \mathrm{~d}$ \\
\hline $\mathbf{P}<$ & $* * *$ & ****: & 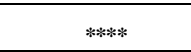 & ****** & ****** & $* * * * *$ \\
\hline \multicolumn{7}{|c|}{ Rice-white corn composite flour } \\
\hline 17\% White corn flour & $9.80 \pm 0.01 \mathrm{~d}$ & $90.20 \pm 0.01 \mathrm{a}$ & $7 \pm 0.1 \mathrm{~d}$ & $1.52 \pm 0.02 \mathrm{~d}$ & $0.58 \pm 0.02 \mathrm{~d}$ & $90.9 \pm 0.06 \mathrm{a}$ \\
\hline 33 White corn flour & $10.04 \pm 0.05 \mathrm{c}$ & $89.96 \pm 0.05 b$ & $7.8 \pm 0.02 \mathrm{c}$ & $1.88 \pm 0.03 \mathrm{c}$ & $0.84 \pm 0.04 \mathrm{c}$ & $89.48 \pm 0.03 b$ \\
\hline 50 White corn flour & $10.27 \pm 0.04 \mathrm{~b}$ & $89.73 \pm 0.04 c$ & $8.61 \pm 0.04 \mathrm{~b}$ & $2.22 \pm 0.05 b$ & $1.1 \pm 0.01 \mathrm{~b}$ & $88.07 \pm 0.07 \mathrm{c}$ \\
\hline 67\% White corn flour & $10.5 \pm 0.02 \mathrm{a}$ & $89.5 \pm 0.02 \mathrm{~d}$ & $9.42 \pm 0.02 \mathrm{a}$ & $2.55 \pm 0.03 \mathrm{a}$ & $1.36 \pm 0.03 \mathrm{a}$ & $86.67 \pm 0.06 \mathrm{~d}$ \\
\hline $\mathbf{P}<$ & $* * * * *$ & $* * * *$ & $* * * *$ & ****** & $* * * *$ & ****** \\
\hline
\end{tabular}

Each record is a mean value of three replicates and is followed by the standard deviation: means in the same column with

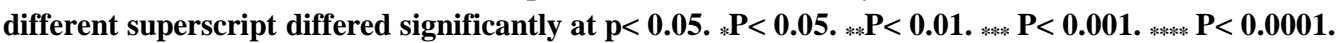

Table (4): Physical properties of rice, chickpea white corn flours and its blends.

\begin{tabular}{|c|c|c|c|c|}
\hline Constituents & Bulk density (g/ml) & $\begin{array}{c}\text { Packed } \\
\text { density }(\mathrm{g} / \mathrm{ml})\end{array}$ & $\begin{array}{l}\text { Water absorption capacity } \\
\text { (WAC) } \mathrm{ml} / \mathrm{g}\end{array}$ & $\begin{array}{c}\text { Oil absorption } \\
\text { capacity }(\text { OAC) } \mathrm{ml} / \mathrm{g}\end{array}$ \\
\hline Rice flour & $0.84 \pm 0.03 b$ & $0.74 \pm 0.01 \mathrm{a}$ & $0.81 \pm 0.02 \mathrm{c}$ & $0.57 \pm 0.01 \mathrm{c}$ \\
\hline White corn flour & $0.76 \pm 0.03 c$ & $0.67 \pm 0.01 \mathrm{~b}$ & $1.04 \pm 0.04 \mathrm{~b}$ & $0.87 \pm 0.03 \mathrm{~b}$ \\
\hline Chickpea flour & $1.05 \pm 0.01 \mathrm{a}$ & $0.59 \pm 0.01 \mathrm{c}$ & $1.89 \pm 0.02 \mathrm{a}$ & $1.16 \pm 0.01 \mathrm{a}$ \\
\hline $\mathbf{P}<$ & ****** & ***** & **:**: & ***** \\
\hline \multicolumn{5}{|c|}{ Rice- chickpea composite flour } \\
\hline $5 \%$ chickpea flour & $0.83 \pm 0.04 \mathrm{c}$ & $0.74 \pm 0.04 \mathrm{a}$ & $0.86 \pm 0.02 \mathrm{~d}$ & $0.59 \pm 0.05 \mathrm{~d}$ \\
\hline $10 \%$ chickpea flour & $0.86 \pm 0.03 \mathrm{~b}$ & $0.71 \pm 0.03 \mathrm{~b}$ & $0.92 \pm 0.05 \mathrm{c}$ & $0.62 \pm 0.01 \mathrm{c}$ \\
\hline $15 \%$ chickpea flour & $0.88 \pm 0.01 \mathrm{a}$ & $0.69 \pm 0.01 \mathrm{c}$ & $0.97 \pm 0.01 \mathrm{~b}$ & $0.65 \pm 0.02 b$ \\
\hline $20 \%$ chickpea flour & $0.89 \pm 0.02 \mathrm{a}$ & $0.68 \pm 0.05 \mathrm{c}$ & $1.03 \pm 0.04 \mathrm{a}$ & $0.68 \pm 0.01 \mathrm{a}$ \\
\hline $\mathbf{P}<$ & $* * * *$ & $* * * * *$ & $* * * * *$ & $* * * * *$ \\
\hline \multicolumn{5}{|c|}{ Rice- corn composite flour } \\
\hline 17\% White corn flour & $0.82 \pm 0.01 \mathrm{a}$ & $0.73 \pm 0.01 \mathrm{a}$ & $0.83 \pm 0.01 \mathrm{c}$ & $0.61 \pm 0.01 \mathrm{~d}$ \\
\hline 33 White corn flour & $0.81 \pm 0.03 \mathrm{ba}$ & $0.72 \pm 0.07 \mathrm{a}$ & $0.87 \pm 0.07 \mathrm{bc}$ & $0.65 \pm 0.01 \mathrm{c}$ \\
\hline 50 White corn flour & $0.80 \pm 0.04 \mathrm{ba}$ & $0.71 \pm 0.03 \mathrm{ba}$ & $0.92 \pm 0.01 \mathrm{ba}$ & $0.71 \pm 0.01 \mathrm{~b}$ \\
\hline 67\% White corn flour & $0.79 \pm 0.03 \mathrm{ba}$ & $0.69 \pm 0.05 b$ & $0.96 \pm 0.06 \mathrm{a}$ & $0.77 \pm 0.02 \mathrm{a}$ \\
\hline $\mathbf{P}<$ & *** & *** & $*$ & $* *$ \\
\hline
\end{tabular}

Each record is a mean value of three replicates and is followed by the standard deviation: means in the same column with different superscript differed significantly at $\mathbf{p}<0.05$. ${ }_{*} \mathrm{P}<0.05$. $* \mathrm{P}<0.01$. ${ }_{* * * *} \mathrm{P}<0.001$. ${ }_{* * * * *} \mathrm{P}<0.0001$.

was low in white corn flour compared to rice flour. So, packed density of two types of flour blends was decreased by increasing replacing levels. The results of bulk density of white corn flour confirmed those of Abiose and Ikujenlola (2014).

Water absorption capacity (WAC) and oil absorption capacity (OAC) of chickpea flour were higher than those of rice or white corn; also they were more in white corn flour compared to rice flour. So, WAC and OAC of two types of flour blends increased by increasing levels of chickpea or white corn flour. These results may be due to the fact that white corn or chickpea flour has high content of protein compared to rice flour. Protein enhances the interaction between the binding forces which in turn increases the gelling ability of flour as found by Lawal et al. (2004) and Shad et al. (2013). It could be also due to the fact that chickpea flour contained soluble fiber as reported by Akubor and Badifu (2004). Alse, chickpea flour contains several hydrophilic components, such as polysaccharides, which have a high WAC 
according to Kaur and Singh (2005). Also, the results of rice- chickpea flour blends are in agreement with those of Ionescu et al. (2009) and Fenn et al. (2010). They found that the increase of utilization of legumes in flour blends such as chickpea flour and protein concentrates displayed good water and oil absorption capacities, protein solubility and emulsifying capacity. Also, all these results are in agreement with those of Wani and Kumar (2014) and (2015).

\subsection{Amylograph characteristics of rice, white corn flours and its blends}

Data in Table (5) showed the amylograph characteristics of rice, white corn flour and its blends. The initial gelatination temperature (IGT) of rice- chickpea flour blends was increased compared to rice flour. On the other hand, the IGT of rice flour was lower than that of white corn flour, but IGT values of rice-white flour blends were increased compared to rice flour. The result of IGT of rice flour was accoreding with those of Wang et al., (2010). They reported that the IGT of rice flour were $53.3-58^{\circ} \mathrm{C}$. The result of IGT of corn flour agreed with those of Malumba et al. (2009). They found that IGT of white corn were $73-80^{\circ} \mathrm{C}$.

The gelatinization temperature GT of rice flour was lower than that of white corn flour. The GT of two types of composite flour was decreased by increasing the levels of chickpea or corn flour. The results of IGT and GT of flour blends may be due to the differences in the chemical composition of rice flour compared to chickpea or white corn flour as shown in Table (3). Thus, the gelling and viscosity properties of composite flour were improved by increasing the levels of substitution. These results may be due to the increasing of WAC as the contents of protein and fibre in ricechickpea or white corn composite flours were increased. These results confirmed those obtained by Balasubramanian et al. (2012).

Maximum gelatinization Max $\mathrm{G}$ of rice flour was more than that of white corn flour. It was decreased by increasing chickpea or white corn flour levels. Finally, according to the amylograph characteristics of flour blends, it could be used these composite flours in many baked products as cake and pan bread. These results are in agreement with those of Ammar and Abed El-Razik (2013). Moreover, these results confirmed those of Sajilata et al. (2006). They found that the gelatinization properties of starches depend on its type, granular structure, botanical origin, and amylose/ amylopectin ratio.

\subsection{Physical properties of pan bread}

Bread development without gluten has involved the use of diverse ingredients and additives with the purpose to imitate the viscoelastic properties of the gluten and consequently to obtain bread-like products (Gallagher et al., 2004). Also, water absorption is considered an important characteristic of flour. High water absorption is required for good bread characteristics which remain soft for a long time (El-Sisy et al., 2014). Thus, rice with $20 \%$ chickpea and rice with $67 \%$ white corn composite flour were used to prepare pan bread with high quality.

Data in Table (6) showed the effect of increasing water levels on the physical properties of rice pan bread. Baking loss of rice-chickpea pan bread was decreased, but it was increased in ricewhite corn by increasing the levels of water. So, weight of rice-white corn pan bread was decreased, but, it was increased with rice-chickpea pan bread. These results may be due to WAC of rice-chickpea composite flour, which was higher than that of rice-white corn as found in Table (4). As a result, the optimum absorption represents the maximum amount of water, as a percentage of the flour weight that will produce a high yield of bread during the baking process as reported by Edmund and Perry (2008).

Furthermore, the increasing of water content of the dough increases the amount of free water in the bread dough, raising the water content of the finished product as reported by Gil et al. (1997). Also, the result of pan bread weights agreed with those of Puhr and Appolonia (1992). They found that the total bread weight of the high-absorption flour was greater than the weight of the low absorption flour.

The volume of rice-chickpea pan bread gradually decreased, but its weight increased. So, the specific volume (SV) decreased by increasing the levels of water. thus, the highest SV was found at the $70 \%$ water level. This might be due to the modification of viscoelastic properties, as a result of competition for the water availability between the protein of chickpea and starch which resulted in a delay in starch gelatinization and, therefore low expansion in the gelatination as reported by Wani and Kumar (2015). But the volume of rice-white corn pan bread samples increased, but weight decreased by increasing water levels. So, the specific volume $S V$ gradually increased, the highest level recorded at $100 \%$ water, but it decreased at $110 \%$ water. These results agreed with those of Różyło et al. (2015). Also, the 
Table (5): Amylograph characteristics of rice, white corn flours and its blends.

\begin{tabular}{|l|c|c|c|}
\hline Constituents & $\begin{array}{c}\text { Initial gelatination } \\
\text { temperature (IGT) }{ }^{\circ} \mathbf{C}\end{array}$ & $\begin{array}{c}\text { Gelatinization } \\
\text { temperature (GT) }{ }^{\circ} \mathbf{C}\end{array}$ & $\begin{array}{c}\text { Maximum gelatinization } \\
\text { (Max G) AU }\end{array}$ \\
\hline \multicolumn{5}{|c|}{ Rice-chickpea composite flour } \\
\hline Rice flour & 58 & 85 & 2960 \\
\hline $\mathbf{5 \%}$ chickpea flour & 63 & 84 & 2900 \\
\hline $\mathbf{1 0 \%}$ chickpea flour & 63 & 79 & 2700 \\
\hline $\mathbf{1 5 \%}$ chickpea flour & 69 & 78 & 2520 \\
\hline $\mathbf{2 0 \%}$ chickpea flour & 69 & 76 & 2390 \\
\hline \multicolumn{4}{|c|}{ Rice-white corn composite flour } \\
\hline White corn flour & 75 & 93 & 2040 \\
\hline \begin{tabular}{l|l|l|} 
17\% White corn \\
flour
\end{tabular} & 69 & 87 & 1280 \\
\hline $\mathbf{3 3}$ White corn flour & 69 & 86 & 1210 \\
\hline $\mathbf{5 0}$ White corn flour & 69 & 87 & 1040 \\
\hline $\mathbf{6 7}$ White corn flour & 68 & 86 & \\
\hline
\end{tabular}

AU: Brabender amylograph units.

Table (6): Physical properties of pan bread.

\begin{tabular}{|c|c|c|c|c|}
\hline Constituents & Baking $\operatorname{loss}(\mathrm{g})$ & Volume (cm3) & Wight (g) & $\begin{array}{l}\text { Specific volume } \\
(\mathrm{cm} 3 / \mathrm{g}))\end{array}$ \\
\hline \multicolumn{5}{|c|}{ Rice pan bread with $20 \%$ chickpea flour } \\
\hline 70\% water & $26.35 \pm 0.05 \mathrm{a}$ & $895.375 \pm 2.88 \mathrm{a}$ & $378.25 \pm 1.93 \mathrm{e}$ & $2.37 \pm 0.05 \mathrm{a}$ \\
\hline $80 \%$ water & $23 \pm 0.1 \mathrm{~b}$ & $890.625 \pm 1.19 \mathrm{ba}$ & $385 \pm 2 d$ & $2.31 \pm 0.01 \mathrm{a}$ \\
\hline $90 \%$ water & $21.4 \pm 0.05 c$ & $883.125 \pm 1.01 \mathrm{~b}$ & $393 \pm 2.65 c$ & $2.25 \pm 0.02 b$ \\
\hline $100 \%$ water & $17.62 \pm 0.05 \mathrm{~d}$ & $868.75 \pm 1.87 \mathrm{c}$ & $411.81 \pm 0.73 b$ & $2.1 \pm 0.03 c$ \\
\hline $110 \%$ water & $14.58 \pm 0.02 \mathrm{e}$ & $845.48 \pm 0.50 \mathrm{~d}$ & $426.81 \pm 1.57 \mathrm{a}$ & $1.98 \pm 0.01 \mathrm{~d}$ \\
\hline $\mathbf{P}<$ & $* * * *$ & ****** & $* * * *$ & $* * * * *$ \\
\hline \multicolumn{5}{|c|}{ Rice pan bread with $67 \%$ corn flour } \\
\hline 70\% water & $13.84 \pm 0.01 \mathrm{e}$ & $798.52 \pm 2.82 b c$ & $430.8 \pm 1.06 \mathrm{a}$ & $1.85 \pm 0.01 \mathrm{c}$ \\
\hline $80 \%$ water & $15.5 \pm 0.04 d$ & $823.75 \pm 1.64 b$ & $422.37 \pm 1.64 b$ & $1.95 \pm 0.01 \mathrm{cb}$ \\
\hline $90 \%$ water & $17.2 \pm 0.02 \mathrm{c}$ & $847.5 \pm 0.87 \mathrm{ba}$ & $418.25 \pm 0.90 c$ & $2.03 \pm 0.01 \mathrm{~b}$ \\
\hline $100 \%$ water & $20.13 \pm 0.05 b$ & $900 \pm 1.00 \mathrm{a}$ & $400.35 \pm 2.54 d$ & $2.25 \pm 0.20 \mathrm{a}$ \\
\hline $110 \%$ water & $21.1 \pm 0.1 \mathrm{a}$ & $750 \pm 2.24 c$ & $384.5 \pm 1.80 \mathrm{e}$ & $1.95 \pm 0.01 \mathrm{cb}$ \\
\hline $\mathbf{P}<$ & $* * * * *$ & $* * * *$ & $* * * *$ & $* * * *$ \\
\hline
\end{tabular}

Each record is a mean value of three replicates and is followed by the standard deviation: means in the same column with different superscript differed significantly at $\mathrm{p}<0.05 . * \mathrm{P}<0.05 . * \mathrm{P}<0.01 . * * * \mathrm{P}<0.001 . * * * * \mathrm{P}<0.0001$.

highest SV was recorded for rice-chickpea pan bread compared to corn-rice pan bread, these results confirmed those of Hager et al. (2012) and Różyło et al. (2015). They found that rice bread was characterized by significantly higher in specific volumes in comparison to corn bread. These results are in parallel with those previously reported in Table (5). These results confirmed those of Herranz et al. (2016). They reported that supplemented of gluten-free muffins with chickpea flour resulted in lower gas retention and lower expansion of muffins and the specific volume was decreased with increasing the levels of chickpea flour.

\subsection{Sensory properties of pan bread}

Data presented in Table (7) showed the effect of different levels of water on sensory properties of pan bread samples. The crust color and crumb color were gradually increased in rice-chickpea pan bread. But they were not changed with ricewhite corn pan bread. These results may be due to the decrease ratio of the yellow color of carotenes than that found in chickpea flour. These results agreed with those of Mondal and Datta (2008). They reported that color development is a function of moisture content, baking temperature and time period during the baking process.

Cell distribution and texture slightly increased with increasing levels of water, but they decreased at $110 \%$ water in two types of pan bread samples. Moreover, the highest general appearance of two types of bread was found at $80 \%$ water. But, as a result of increasing level of water, general appearance slightly decreased. These results were might be due to the larger holes that found between crust and crumb when the added water is too high or proofing is extended as reported by Gómez 
Table (7): Sensory properties of pan bread as affected by different levels of water.

\begin{tabular}{|c|c|c|c|c|c|c|c|c|}
\hline Constituents & $\begin{array}{c}\text { Crust } \\
\text { color (10) }\end{array}$ & $\begin{array}{c}\text { Crumb } \\
\text { color(10) }\end{array}$ & $\begin{array}{c}\text { Texture } \\
\text { (10) }\end{array}$ & $\begin{array}{c}\text { Cell } \\
\text { distribution } \\
(10)\end{array}$ & Odor (10) & Taste(10) & $\begin{array}{c}\text { General } \\
\text { appearance } \\
(10)\end{array}$ & $\begin{array}{c}\text { Average } \\
\text { (10) }\end{array}$ \\
\hline \multicolumn{9}{|c|}{ Rice pan bread with $20 \%$ chickpea flour } \\
\hline $70 \%$ water & $7 \pm 0.47 \mathrm{c}$ & $6.4 \pm 0.52 b$ & $7 \pm 0.47 \mathrm{c}$ & $7.5 \pm 0.53 b$ & $6.5 \pm 0.5 \mathrm{c}$ & $6 \pm 0.62 \mathrm{c}$ & $6.5 \pm 0.53 b$ & $6.7 \pm 0.24 c$ \\
\hline $80 \%$ water & $7.6 \pm 0.52 b$ & $6.7 \pm 0.48 b$ & $7.5 \pm 0.53 \mathrm{cb}$ & $8 \pm 0.82 \mathrm{ba}$ & $8 \pm 0.47 b$ & $7.2 \pm 0.42 b$ & $7 \pm 0.35 \mathrm{a}$ & $7.43 \pm 0.10 \mathrm{ba}$ \\
\hline 90\% water & $8 \pm 0.47 \mathrm{ba}$ & $7 \pm 0.47 \mathrm{ba}$ & $8.3 \pm 0.48 \mathrm{ab}$ & $8.3 \pm 0.67 \mathrm{a}$ & $8.4 \pm 0.52 \mathrm{a}$ & $8.1 \pm 0.32 \mathrm{a}$ & $6.5 \pm 0.47 \mathrm{~b}$ & $7.7 \pm 0.15 a$ \\
\hline $100 \%$ water & $8.1 \pm 0.32 \mathrm{ba}$ & $7.4 \pm 0.52 \mathrm{a}$ & $8 \pm 0.67 \mathrm{ba}$ & $8.1 \pm 0.39 \mathrm{ba}$ & $8.5 \pm 0.47 a$ & $8.2 \pm 0.42 \mathrm{a}$ & $6.4 \pm 0.39 b$ & $7.843 \pm 0.18 \mathrm{a}$ \\
\hline $110 \%$ water & $8.2 \pm 0.48 \mathrm{a}$ & $7.55 \pm 0.50 \mathrm{a}$ & $7.7 \pm 0.48 \mathrm{~b}$ & $7.8 \pm 0.35 \mathrm{ba}$ & $8.5 \pm 0.53 \mathrm{a}$ & $8.4 \pm 0.52 \mathrm{a}$ & $6.3 \pm 0.48 \mathrm{~b}$ & $7.72 \pm 0.14 \mathrm{a}$ \\
\hline $\mathbf{P}<$ & ****** & ****** & ****** & $*$ & $* * * *$ & **** & $*$ & $* * * *$ \\
\hline \multicolumn{9}{|c|}{ Rice pan bread with $67 \%$ corn flour } \\
\hline 70\% water & $7 \pm a$ & $7.9 \pm 0.57 \mathrm{a}$ & $7.2 \pm 0.42 \mathrm{c}$ & $7.2 \pm 0.35 \mathrm{c}$ & $6.9 \pm 0.21 \mathrm{c}$ & $7 \pm 0.15 c$ & $6.4 \pm 0.52 \mathrm{ba}$ & $7.126 \pm 0.07 \mathrm{c}$ \\
\hline $80 \%$ water & $7.1 \pm 0.21 \mathrm{a}$ & $8.1 \pm 0.74 a$ & $7.8 \pm 0.48 b$ & $7.9 \pm 0.32 b$ & $7.2 \pm 0.34 c$ & $7.50 .21 \pm b$ & $7.2 \pm 0.21 \mathrm{a}$ & $7.54 \pm 0.18 b$ \\
\hline 90\% water & $7.2 \pm 0.42 \mathrm{a}$ & $8.2 \pm 0.63 \mathrm{a}$ & $8.3 \pm 0.48 \mathrm{ba}$ & $8.4 \pm 0.52 \mathrm{ba}$ & $7.6 \pm 0.69 \mathrm{~b}$ & $7.70 .42 \pm \mathrm{ba}$ & $6.7 \pm 0.42 \mathrm{ba}$ & $7.73 \pm 0.24 \mathrm{a}$ \\
\hline $100 \%$ water & $7.2 \pm 0.42 \mathrm{a}$ & $8.3 \pm 0.48 a$ & $8.65 \pm 0.41 \mathrm{a}$ & $8.7 \pm 0.48 \mathrm{a}$ & $7.7 \pm 0.34 \mathrm{ba}$ & $7.80 .25 \pm$ ba & $6.55 \pm 0.44 \mathrm{ba}$ & $7.845 \pm 0.08 \mathrm{a}$ \\
\hline $110 \%$ water & $7.2 \pm 0.79 \mathrm{a}$ & $8.3 \pm 0.48 \mathrm{a}$ & $8.2 \pm 0.42 \mathrm{ba}$ & $8.25 \pm 0.42 \mathrm{ba}$ & $8 \pm 0.4 a$ & $7.9 \pm 0.47 \mathrm{a}$ & $6.4 \pm 0.46 \mathrm{ba}$ & $7.78 \pm 0.23 a$ \\
\hline $\mathbf{P}<$ & -- & -- & $* * * *$ & $* * * *$ & $* * * *$ & $* * * *$ & $*$ & $* * *$ \\
\hline
\end{tabular}

Each record is a mean value of ten replicates and is followed by the standard deviation: means in the same column with different superscript differed significantly at $\mathrm{p}<0.05$. $* \mathbf{P}<0.05 . * \mathrm{P}<0.01 . * * * \mathrm{P}<0.001 . * * * * \mathrm{P}<0.0001$.

and Sciarini (2015). Taste and odor were improved by increasing the water content in both types of pan bread samples. These results may be due to the ratio of bean and chickpea flour, which decreased by increasing the water content. These results agreed with those of Marco and Rosell (2008). They observed that the addition of chickpea flour causes a soar in water absorption and modify textural properties of bread. Also Ouazib et al., (2016) reported that chickpea flour could be used for obtaining gluten free breads with the nutritional characteristics of the legumes and acceptable sensory characteristics.

\section{Conclusion}

Gluten free composite flour contains rice and chickpea or rice and white corn showed good chemical and physical properties. thus, it can be used to prepare pan bread with high quality. Also, the increasing level of water can improve the physical properties and sensory properties of gluten free pan bread.

\section{REFERENCES}

A.A.C.C (2000). American Association of cereal chemists. Cereal laboratory method. American Association chemists, INC. St. Paul. Minnesota. U.S.A.

A.O.A.C (2005). Official Methods of Analysis. Association of Official Analytical Chemists. $18^{\text {th }}$ Ed. Washington, D.C., USA.

Abiose S. H. and Ikujenlola A.V. (2014). Comparison of chemical composition, functional properties and amino acids composition of quality protein maize and common maize (Zea may L). Afr. J. Food Sci. Tech., 5 (3) : 81-89.

Ahmed H. F. (2013). Effect of fortification pan bread with lupine flour on the chemical, rheological and nutritional properties. J. Food and Dairy Sci.; Mansoura Univ., 4 (3): $65-75$.

Akubor P. I. and Badifu G. I. O. (2004). Chemical composition, functional properties and baking potential of African breadfruit kernel and wheat flour blends. Int'l. J. Food Sci. and Tech., 39: 223-229.

Alajaji S. A. and El-Adawy T. A. (2006). Nutritional composition of chickpea (Cicer arietinum L.) as affected by microwave cooking and other traditional cooking methods. J. Food Comp and Anal., 19: 806-812.

Ammar A. S. M. and Abd El-Razik M. M. (2013). Quality characteristics of gluten free cake produced from cassava, pumpkin and potato flour J. Food and Dairy Sci.; Mansoura Univ., 4 (8): 401 412.

Balasubramanian S., Borah A. and Mahanta C. L. (2012). Rheological and nutritional properties of legumes incorporated corn Extrudates. Int. J. Food Res., 19 (3): 971975.

Begum R., Uddin M. J., Rahman M. A. and Islam M. S. (2013). Comparative study 
on the development of maize flour based composite bread J. Bangladesh Agri. Univ., 11 (1): 133-139.

De la Hera E.,Talegón M., Caballero P. and Gómez M. (2013). Influence of maize flour particle size on gluten-free breadmaking. J. Sci Food Agric., 93: 92432.

Edmund J. T. and Perry K. W. (2008). Soft Wheat Quality. In: Food Engineering Aspects of Baking Sweet Goods. Servet G. S. and Serpil S. (Eds) pp. 1-30, CRC Press.

El-SisyT.T., Ali J.B. and Masoud M.S. (2014). Effect of using sorghum on the quality of wheat mixtures and their flour. J Food and Dairy Sci., Mansoura Univ., 5 (12): 919 942.

Fenn D., Lukow O. M., Hummphreys G., Fields P.G. and Boye J. I. (2010). Wheat-legume composite flour quality. Int'l. J. Food Proper., 13: 381-393.

Gallagher E., Gormley T. R. and Arendt E. K. (2004). Recent advances in the formulation of gluten-free cereal-based products. Trends in Food Sci., Tech., 15, 143- 152.

Gil M. J., Callejo M. J. and Rodrõ Âguez G. (1997). Effect of water content and storage time on white pan bread quality: instrumental evaluation. $\mathrm{Z}$ Lebensm Unters Forsch A., 205: 268 - 273.

Gómez M. and Sciarini L.S. (2015). GlutenFree Bakery Products and Pasta. In Advances in the Understanding of Gluten Related Pathology and the Evolution of Gluten-Free Foods. Arranz E, FernándezBañares F, Rosell CM, Rodrigo L, Peña AS, (eds). Omnia Science., p. 565-60, Barcelona, Spain

Gujral H.S. and Rosell C.M. (2004). Improvement of the breadmaking quality of rice flour by glucose oxidase. Food Res. Int'1., 37: 75-81.

Hager A.S., Wolter A., Czerny M., Bez J., Zannini E., Arendt E.K. and Czerny M. (2012). Investigation of product quality, sensory profile and ultrastructure of breads made from a range of commercial gluten-free flour compared to their wheat counterparts. Europ. Food Res. Tech., 235: 333-344.

Hegazy A.I., Ammar M.S. and Ibrahium M.I. (2009). Production of Egyptian glutenfree bread. World J. Dairy and Food Sci.,
4(2): 123-128.

Herranz B., Canet W., Jiménez M., Fuentes R. and Alvarez M.D. (2016). Characterization of chickpea flour-based gluten-free batters and muffins with added biopolymers: rheological, physical and sensory properties. Int'l. J. Food Sci., Tech., 51: 1087-1098.

Hussein A. M. S., Kamil M. M., Hegazy N. A. and Abo El-Nor S. A. H. (2013). Effect of wheat flour supplementation on balady bread quality. Pol. J. Food Nutr. Sci., 63, (1): 11-18.

Ionescu A., Aprodu I., Darabă A., Gurău G., Baciu C. and Nichita A. (2009). Chemical and functional characterization of chickpea protein derivates. The Annals of the University Dunarea de Jos of Galati Fascicle VI - Food Technology, New Series Year., 33: 16-27.

Izembaeva A. K. B., Muldabekova Z. H. I., Iztaev A. and Zhienbaeva S.T. (2013). The use of composite mixtures in the production of biscuits. Bulge. J. Agric. Sci., 19: 28-31.

Kaur M. and Singh N. (2005). Studies on functional, thermal and pasting properties of flour from different chickpea (Cicer arietinum L.) cultivars. Food Chem., 91: 403-411.

Korus J., Grzelak K., Achremowicz K. and Sabat R. (2006). Influence of prebiotic additions on the quality of gluten-free bread and on the content of inulin and fructooligosaccharides, Food Sci. Tech. Int'l., 12: 489-495.

Lawal O. S., Adebowale K. O. and Oderinde R. A. (2004). Functional properties of amylopectin and amylose fractions isolated from bambarra groundnut (Voandzeia subterranean) starch. Afr. J. Bioctech., 31 (8): 399-404.

Lazaridou A., Duta D., Papageorgiou M., Belc N. and Biliaderis C. (2007). Effects of hydrocolloids on dough rheology and bread quality parameters in gluten free formulations. J. Food Eng., 79: 10331047.

Lopez A. C. B., Pereira A. J. G. and Junqueira R. G. (2004). Flour mixture of rice flour, corn and cassava starch in the production of gluten-free white bread. Brazilian Archi. Biol. Tech., 47: 63-70.

Malumba P., Massaux C., Deroanne C., Masimango T. and Béra F. (2009). Influence of drying temperature on functional 
properties of wet-milled starch granules. Carb. Polymers. 75: 299-306.

Man S., Păucean A. Muste S. and Pop A.(2015 ). Effect of the Chickpea (Cicer arietinum L.) Flour Addition on Physicochemical Properties of Wheat Bread. Bull. UASVM Food Sci., and Tech.,72(1):41-49.

Marco C. and Rosell C.M. (2008). Breadmaking performance of protein enriched, glutenfree breads. Eur. Food Res. Tech., 227:1205-1213.

Mariotti M., Lucisano M., Pagani M. A. and Ng P.K. (2009). The role of corn starch, amaranth flour, pea isolate, and Psyllium flour on the rheological properties and the ultrastructure of gluten free doughs. Food Res., Int'l., 42: 963-975.

Mirzaei M. and Movahed S. (2013). Evaluation of staling rate and quality of gluten-free toast breads on rice flour basis. Res. J. Appl. Sci. Eng. Tech., 5 (1): 224-227.

Mishra N. and Chandra R. (2012). Development of functional biscuit from soy flour \& rice bran. Int'1. J. Agric. Food Sci., 2 (1): 1420.

Mollakhalili Meybodi N., Mohammadifar M. A. and Feizollahi E. (2015). Gluten-Free Bread Quality: A Review of the Improving Factors. J. Food Qual. Hazards Control, 2 (3): 81-85.

Mondal A. and Datta A.K. (2008). Bread baking- A review. J. Food Eng. , 86: (4):465-474.

Moore M.M., Schober T.J., Dockery P. and Arendt E.K. (2004). Textural comparisons of gluten-free and wheat-based doughs, batters, and breads. Cereal Chem., 81 (5): 567-575.

Mpotokwane S. M., Gaditlhatlhelwe A., Sebaka A. and Jideani V. A. (2008). Physical properties of Bambara groundnuts from Botswana. J. Food Eng., 89: 93-98.

Ouazib M., Garzon R., Zaidi F. and Rosell C.M. (2016). Germinated, toasted and cooked chickpea as ingredients for bread making. J. Food Sci Tech., 53(6):2664-2672.

Oyeyinka S.A., Oyeyinka A.T., Karim O.R., Kayode R. M. O., Balogun M. A. and Balogun O. A. (2013). Quality satributes of Weevils (Callosobruchus maculatus) infested cowpea (Vigna unguiculata) products. Nig. J. Agric. Food and Environ., 9 (3): 16-22.

Padalino L., Conte A. and Nobile A.D. (2016). Overview review on the general approaches to improve gluten-free pasta and bread. J. foods., 5 (4): 87-104.

Puhr D.P. and Appolonia B.L.D. (1992). Effect of Baking Absorption on Bread Yield, Crumb Moisture, and Crumb Water Activity. Cereal Chem., 69 (5): 582-586.

Roshid M., Wazed A., Islam R., Mahomud S. and Khatun H. (2016). Preparation of gluten free bread using the mixture of different cereals grain flour. Int'1. J. Adv. Multidiscip. Res., 3 (5): 9-16.

Różyło R., Dziki D., Gawlik-Dziki U., CacakPietrzak G., Miś A. and Stanisław Rudy S. (2015). Physical properties of gluten-free bread caused by water addition. Nt. Agrophys., 29: 353-364.

Sajilata M. G., Singha R. S. and Kukarni P. R. (2006). Resistance starch-a review. Comprehensive Rev. in Food Sci. Food Safety., 51: 1-17.

Schober T. J., Moreau R. A., Bean S. R. and Boyle D. L. (2010). Removal of surface lipids improves the functionality of commercial zone in viscoelastic Zeinstarch dough for gluten-free bread making. J. Cereal Sci., 52 (3): 417-425.

Sciarini L.S., Ribotta P. D., León A. E. and Pérez G.T. (2010). Influence of glutenfree flour and their mixtures on batter properties and bread quality. Food Bioproc. Tech., 3:577-585.

Shad M. A., Nawaz H., Noor M., Ahmad H. B., Hussain M. and Choudhry M. A. (2013). Functional Properties of maize flour and its blends with wheat flour: optimization of Preparation conditions by response surface methodology. Pak. J. Bot., 45 (6): 2027-2035.

Shittu T. A., Raji A. O. and Sanni A. O. (2007). Effect of baking time and temperature on some physical properties of bread loaf. Food Res. Int'l., 40 (2): 280-290.

SPSS (2008). Spss users Gide statistics version 17.0. Copy right Spss Inc. Washington, D.C. USA.

Torbica A., Hadnađev M. and Dapčević T. (2010). Rheological, textural and sensory properties of gluten free bread formulations based on rice and buckwheat flour. Food Hydrocolloids., 24: 626-632.

Wang L., Xie B., Shi J., Xue S., Deng Q., Wei Y. and Tian B. (2010). Physicochemical properties and structure of starches from Chinese rice cultivars. Food Hydrocolloids, 24: 208-216. 
Wani S. A. and Kumar P. (2014). Comparative study of chickpea and green pea flour based on chemical composition, functional and pasting properties. J. Food Res. Tech., 2 (3): 124-129.

Wani S. A. and Kumar P. (2015). Characterization of extrudates enriched with health promoting ingredients. Food Measure, 9:592-598.
Yaseen A. A., Shouk A. A. and Ramadan M.T. (2010). Corn-wheat pan bread quality as affected by hydrocolloids J. Amer. Sci.; 6 (10): 6 84-690.

Youssef H. M. K. E. (2015). Production of high nutritive value and physical and sensory characteristic wheat biscuits fortified with chickpea flour. Life Sci. J., 12 (6): 193199.

تقييم التركيب الكيميائي والخواص الفيزيقية لمخاليط دقيق خالية من الجلوتين وخواص الجودة لخبز القوالب

$$
\begin{aligned}
& \text { إيمان عبد الحميد أحمد عبد ريه } \\
& \text { قسم الاقتصاد المنزلي ـ كلية التربية النو عية ـ جامعة أسوانـ مصر }
\end{aligned}
$$

تم تجهيز مخاليط دقيق خالية من الجلوتين وذللك باستبدال دفيق الارز بنسب مختلفة بدقيق الحمص، أو الذبرة الكبرة البيضاء.

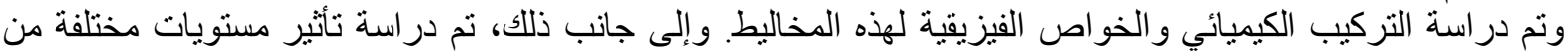

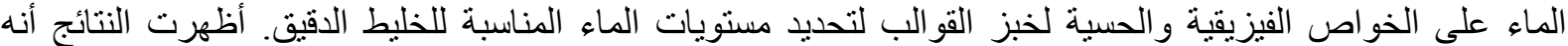

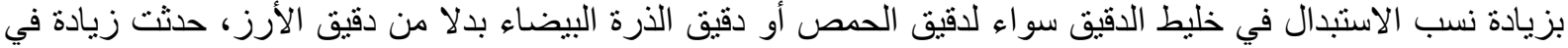

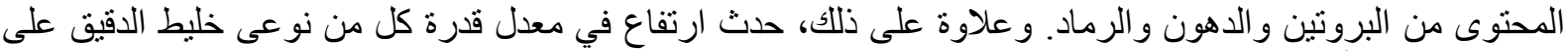

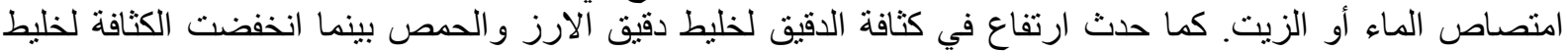

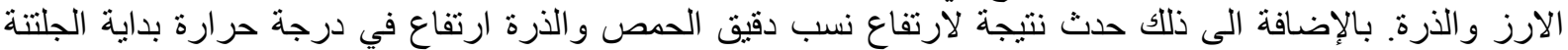

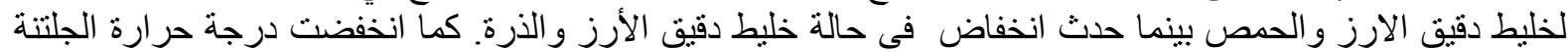

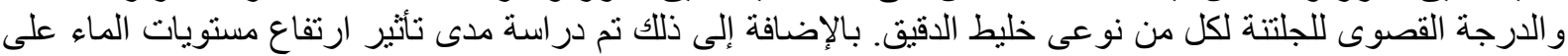

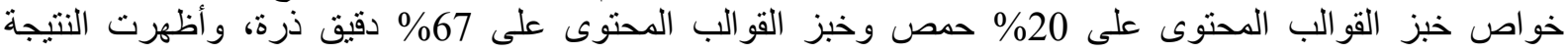

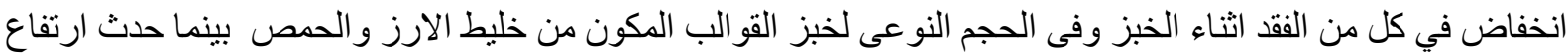

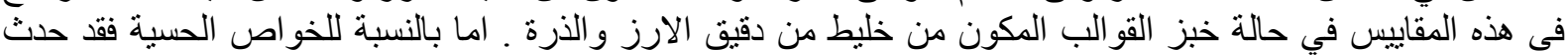

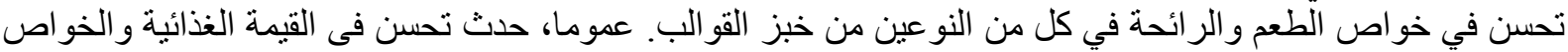

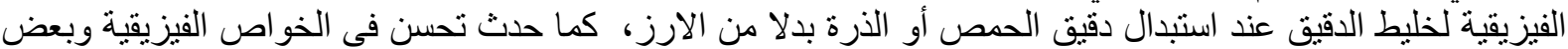

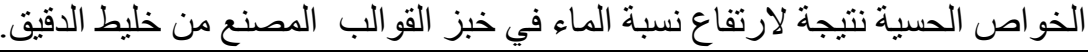

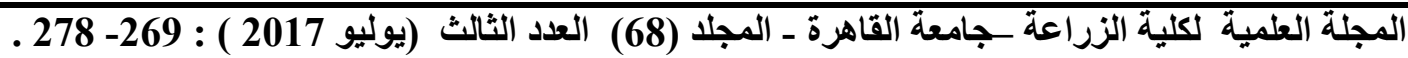

